\title{
ACHIEVING IMPROVED FINANCING FOR LOW-INCOME PRODUCERS IN DEVELOPING COUNTRIES: THE SECOND SET OF APPROACHES
}

M. G. MAIANGWA

(Received 17 June 2012; Revision Accepted 19 September 2012)

\begin{abstract}
The availability of affordable financial capital to the rural population has long been a prime component of development strategy. Many rural businesses rely on borrowed funds to help finance their daily operations, and few have the resources to finance significant expansion of their capital solely with current revenues and retai ned earnings. The general consensus is that with adequate financing, businesses can adjust to market and technological developments in ways that improve the productivity of local resources. This paper reviews the second set of approaches for achieving improved financing for low-income producers in developing countries.
\end{abstract}

KEY WORDS: Approaches, Improved Access, Finance, Low-income, Producers.

\section{INTRODUCTION}

Most of the poor in developing countries consist of micro entrepreneurs who are engaged in agricultural production and non-agricultural activities in areas of widely varying potential (IFAD, 2000). Direct and improved access to financial services, especially credit, will help raise the productivity and incomes of these small producers, in addition to impacting positively on their asset formation and food security (Holt and Ribe, 1991; IFAD, 2000).

However, providing financial services to this diverse group of rural poor is challenging for several reasons. According to Markowski (2001), they are vastly spread geographically, making service delivery and information collection costly; transportation and communication facilities are weak; production is weather-dependent and risky; farmers all want to borrow of the same time; many of the poor are illiterate; and the poor have few assets to propose as collateral for loans. As a result, rural clients usually turn to locally-based informal sources such a family, friends, or moneylenders, who lend only small amounts for short periods of time and at rates that are higher than those of the formal sources (Feder et al., 1986; Leite and Sundararajan, 1990; Braverman and Huppi, 1991; Fiebig, 1999).

Studies (Markowski, 2001; Holt and Ribe, 1991; Lycette and White, 1989) have shown that insufficient access to capital forces the poor to engage in less productive farm and non-farm enterprises, thus foregoing income. It limits poor householdsôability to cushion themselves against adverse fluctuations in their incomes and in their basic needs for food, shelter, clothing, education, and medical services. Also, with insufficient working capital, small businesses must wait for proceeds to accumulate before they can purchase materials. This commonly results in inefficiency and discontinuities in products and sales. In addition, small businesses are seldom able to take advantage of quantity discounts on raw materials. Moreover, to obtain enough to meet daily living expenses, they must sell their goods immediately, whether market prices are favorable or not.

This paper reviews the second set of approaches for improving low-income producers access to financing

Second Set of Approaches for Achievement of Improved Financing for Low-Income Producers

Collateral substitutes: Farmers operating in areas where suitable collaterals are not common, or who have few assets useable as collaterals may resort to arrangements which are referred to as collateral substitutes in order to obtain loans or to increase the amount of loans they can obtain (Binswanger et al., 1985). One such collateral substitute is a third party guarantee. Under this arrangement, a borrower who owns few assets with collateral value and whose own repayment incentives appear to be low to the lender may ask a third party who is perceived as less of a risk by the lender to guarantee repayment in case the borrower defaults. The third party may do so if it has better information about the borrower $\hat{\boldsymbol{\Phi}}$ repayment incentive/capacities, or otherwise gains from the relationship with the borrower other than the borrowing transaction (Binswanger et al., 1985). Another collateral substitute is the ownership of tradeable, durable assets such as machinery, land, televisions and radios, which

M. G. Maiangwa, Department of Agricultural Economics and Rural Sociology, Ahmadu Bello University, Zaria. 
serve as an implicit collateral, since the borrower may have an incentive to generate liquidity by sale of assets rather than lose future borrowing access in the case of default (Feder et al., 1986). In Mali, for example, CAECE (Caisse Associative dâEpargue et de Credit des Entrepreneurs et Commercants de Bamako) has been successful in delivering medium-sized loans to individual entrepreneurs by using physical assets as collateral along with a policy of strict enforcement through deeds authenticated by a notary (Markowski, 2001). A third collateral substitute is the formation of a long-term relationship with a lender, since it helps to reduce the degree of lender uncertainty. If a farmer establishes a long record of good repayment performance, he may obtain access to credit at a level (or terms) which would not be available to him if he did not have such a record (Feder et al., 1986). A fourth collateral substitute is character and/or experience-based individual loans. Typically, the initial loan requires a character reference from a village chief or other persons with a stake in maintaining a reputation for probity and sound judgement. Initial loans are very small but access to gradually increasing loans is assured as long as the borrower maintains a satisfactory repayment record (USAID, 1994). The Badan Kredit Kecamatan (BKK) and the Bank Rakyat Indonesia Unit Desa (BUD) in Indonesia have used the authentic and official leadership in the village to help screen loan applicants and secure prompt loan collection. They have relied on the reputation, authority, and official and social status of the village leader to overcome one of the principal deficiencies of formal RFIs: inadequate information on the creditworthiness of potential borrowers. Also, a sound loan collection record enhanced the status of the village head, who inevitably became the link between formal lenders and the village, both for first-time borrowers and for repeat borrowers who became eligible for larger loans (Yaron, 1994).

Savings-Credit Linkages: In the past, development of financial markets was based on the assumption that lowincome groups, mainly found in rural areas, were too poor to be able to save. As a result, in establishing agricultural credit programmes with their own or external funds, governments paid little attention to the mobilization of internal savings (Braun, 1992). On the lendersôside, mobilization of local savings gives them a reliable, inexpensive, and sustainable source of funds for on-lending (Markowski, 2001). On the borrowersô side, savings discourages haphazard loan use, risky business ventures, and poor repayment morale; helps remove the capital constraint for borrowers, gives them more security (emergency fund) and a greater sense of self-esteem; strengthens self-financing capacity, thereby reducing the demand for expensive credit; and helps in the establishment of a track record by providing inexpensive information to the bank on a customer, which may enter into creditworthiness examinations, that is, helps lenders screen borrowers (Dessing, 1990; Gadway and Oळ0nnell, 1996). Thus, savings are a key component of successful financial service delivery models. Even those who argue that the rural poor do not need more sources of credit for development have difficulty arguing against the need for better deposit facilities (Howse, 1983). Besides, some poor groups are more likely to benefit from credit than others. Berger (1989) and Lipton (1989) argue that the nultrapoorò are unlikely to be good candidates for loans because their subsistence position forces them to use whatever cash they have for consumption. The financial needs of very poor men and women may therefore be best served by increasing their access to interest-bearing deposits (Holt and Ribe, 1991). Savings and credit can be linked, either by setting up a dual-purpose financial institution, or by making loan disbursements conditional on meeting specified savings requirements, that may include savings in kind (Dessing, 1990). Part of the savings fund can be deposited with a bank as collateral for a contractual loan-savings scheme. In such a scheme, a fixed credit-to-savings ratio is recommended, contingent upon the availability of funds. This savings fund can also be used for direct re-lending. In this case, a flexible ratio can be applied that varies with the amount of savings deposited and the number of satisfactory repayment cycles. This encourages both savings and prompt repayment (Seibel, 1989). Savings requirements vary substantially between credit programmes, but certain characteristics are prerequisites for savings programmes, namely, deposits must be secure and accessible and must yield a good return (Holt and Ribe, 1991). What is less clear, however, is whether savings should be mandatory or voluntary, but most programmes that have mobilized savings require regular deposits to participate in the programme (Otero, 1986). For example, at Badan Kredit Kecamatan in Indonesia, borrowers are required to save 3.3 percent of the face value of the loan every month, which helps capitalize the loan fund, insures against default, and gives borrowers a source of funds. Similarly, the Grameen Bank in Bangladesh requires each member to contribute a sum equivalent to 25 percent of the amount of interest the bank charges into an Emergency Fund that acts as insurance coverage against default (Holt and Ribe, 1991). When risks are high and access to funds is limited, it may be appropriate to start financial service programmes with deposit facilities. The Self-Employed Women⿳亠丷厂 Association (SEWA) in India, for example, started as a savings depository for poor women making small deposits. In 1974, SEWẤs mobile units began visiting

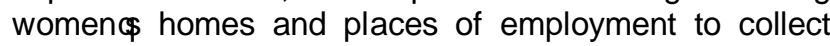
savings and fulfil an unmet demand. Local banks were unable to service such a dispersed and illiterate clientele. SEWA did not disburse any loans until 1976 (Sebstad, 1982). Some authors have also argued that, inspite of much recent enthusiasm for combined savings and credit components, other more profitable forms of savings should be considered as well. According to them, non-monetary assets may keep their value better in periods of inflation or when uncertain and volatile monetary policies are pursued by the government (Dessing, 1990).

Small, incremental loans and flexible repayment arrangements: Small loan sizes can be a key mechanism for targeting the poor. The underlying 
assumption is that the smaller the loan, the poorer the set of people willing to go through the loan application process; fewer poor people are presumed to have access to larger loans (USAID, 1994). Granting loans incrementally, starting with very small amounts, will help adjust the size of loans (at least initially) to amounts clients are used to handling, and to make sure that they understand the principle of interest rates and the potential threat of deepening indebtedness (Grindle et. al., 1987). Repayment cycles should be short to reflect the shorter buy-manufacture-sell cycle of microenterprises. For low-income clients, frequent repayment of smaller amounts is preferable because of high consumption pressures and lack of safe-keeping facilities. It is also argued that frequent loan repayment installments, either weekly or monthly, facilitate a close monitoring of the borrower $\hat{\boldsymbol{s}}$ loan repayment performance. As clients build up a good track record, the loan duration and the loan repayment intervals for repeat loans are often lengthened (Klein et al., 1999). Some microlenders grant increasingly individualized loan products once the borrower has established good creditworthiness. This is often referred to as rgraduationò to a next product level or client status. Alternatively, flexible repayment terms should be granted on an individual basis to match the seasonal pattern and production cycle of enterprises, that is, to make the loans self-liquidating (Dessing, 1990). The Grameen Bank (GB) in Bangladesh introduces poor, inexperienced borrowers to financial discipline by requiring 50 equal weekly loan repayments, followed by two weekly interest payments. The emphasis on routine repayments has been critical to avoid an accumulation of cash among borrowers who could be tempted to spend it rather than use it to meet loan repayments. This rigid pattern of repayment, buttressed by routine meetings of the GB group members in which social pressure is applied to achieve prompt repayments, also saves administrative costs and loan losses. Also, because these meetings are concerned with social, health, and education issues, a common bond between members exists, making voluntary default an occasion for loss of social standing (Yaron, 1994; Yaron, 1995). In the Bank for Agriculture and Agricultural Cooperatives in Thailand, the standard repayment structure requires a balloon repayment of principal and interest eleven months after loan disbursement. Prompt payment was a condition for a follow-up loan one month later. Borrowers unable to pay on time were expected to borrow elsewhere to cover the full amount due, even from moneylenders. Indeed, borrowers in some instances have preferred to incur the high financial costs involved in borrowing from moneylenders rather than lose their borrowing eligibility with BAAC, as well as having to pay the penalty interest rate which was charged on late repayments (Yaron, 1994; Yaron, 1995). Klein et al. (1999) have argued that the possible access to new loans as the previous ones are repaid is a major loan repayment incentive for microcredit borrowers. They also argued that rewards for full and timely loan repayments on the one hand and charging of late payment fees and penalties on the other are effective means of promoting good borrower discipline. The two successful credit institutions in Indonesia --- the BUD and the BKK --- offer a monthly interest rebate on the original loan value for timely repayments $\mathrm{i} 0.5$ percent of the loan for the BUD and 1 percent for the BKK. In view of the declining balances of the loans extended by the BUD and given the typical monthly repayments involved, the rebate has amounted to about 12 percent on an annualized basis for a loan scheduled for repayment in twelve-month installments --- a substantial rebate and an effective incentive for prompt repayment. Another successful credit institution in Thailand $\ddot{i}$ the Bank for Agriculture and Agricultural Co-operatives (BAAC) ï rather than providing a rebate has put into practice a penalty rate of 3 percent per annum on arrears, equivalent to about a quarter of its nominal lending interest rate (Yaron, 1994; Yaron, 1995).

\section{Reform of Agricultural Development Banks:} Agricultural development banks were established several years ago to extend financial services mainly credit at subsidized interest rates to customers not considered creditworthy by commercial banks. They are largely state-owned and funded by governments and international donor agencies. In Africa, these parastatal agricultural credit institutions have been universal failures. According to Klein et al. (1999), as banks were established to channel subsidized donor and government funds to farmers, they lacked the market discipline and incentives of commercial banks. The provision of credit depended upon political decisions and interests. The irregular availability of loan funds, the setting of interest rate ceilings and the periodic write-offs of overdue loans seriously undermined the effectiveness of these banks. Also, as the performance of these banks was measured in terms of loan disbursements rather than in the actual number of small farmerborrowers attended and recovery of outstanding loans, they were tempted to grant sizeable loans predominantly to well-established larger farmers. This was reinforced by the rent-seeking behaviour of these farmers, who benefitted from the subsidized interest rates that were set by governments (Schmidt and Kropp, 1987; Gonzalez-Vega and Graham, 1995). Furthermore, as agricultural development banks focused exclusively on agricultural lending, they were exposed to a high concentration of risks. This required frequent rescheduling of overdue loans, thus further undermining loan recovery efforts and the loan repayment discipline of both bank staff and farmers (Klein et al., 1999). The essence or objective of agricultural development bank reform would be to transform these banks into viable and sustainable providers of financial services to a wideranging rural clientele. To achieve this objective, the following key results are to be achieved:

(i) Activating the political will to reform or to close down.

(ii) Adequate reform strategies (for example, privatization).

(iii) An effective planning process.

(iv) Operational autonomy and freedom from political interference.

(v) An appropriate legal and regulatory framework with prudential norms. 
(vi) Financial re-structuring.

(vii) Organizational re-structuring

(viii)Human resource development, including staff re-training.

(ix) An effective delivery system, with branches as profit-centres.

(x) Demand-driven financial services

(xi) Operational and financial sustainability

(xii)Effective internal control and external supervision (Seibel, 2001).

Credit Guarantee and Insurance Schemes: Credit guarantee schemes are set up with the purpose of covering some portion of the losses incurred when borrowers default on loans The purpose of such schemes is to encourage financial institutions, and in particular commercial banks, to lend to small businesses with viable projects and good prospects of success but which are unable to provide adequate collateral or which do not have a suitable record of financial transactions to prove that they are creditworthy (Levitsky and Prasad, 1990). The basic feature of most guarantee schemes is that the risk of loss is shared in an agreed proportion between the lender and the guarantee organization. Experience indicates that guarantee schemes tend to work best when the guarantees are given for creditworthy clients with good projects who are unable to obtain loans because they cannot satisfy the lender $\hat{s}$ requirement for collateral. Even in developed countries, guarantee schemes that have attempted to provide guarantees for risky borrowers or risky projects have generally run into problems (Levitsky and Prasad, 1990). In Nigeria, the Agricultural Credit Guarantee Scheme Fund (ACGSF) was established in 1977 to encourage banks to engage in agricultural lending by guaranteeing 75 percent of loans disbursed. The ACGSF guarantees loans from $\$ 100,000$ (individual farmers) up to $\mathrm{A} 1,000,000$ (for cooperative societies). No tangible collateral is required for loans of less than $\$ 5,000$ but loans above $\mathrm{N} 20,000$ require collateral of 25 percent of the desired loan amount. The partnership with the private sector takes the form of farmers or cooperative societies who are required to open an account in a participating bank and provide the collateral to apply. All loans must be insured by the Nigerian Agricultural Insurance Company (NAIC). From 1978 to 1986, the loans were made of subsidized rates, but after deregulation, market interest rates prevailed. The number and volume of loans guaranteed have been on the rise since 1999, averaging 17 percent growth in number and nearly 50 percent growth in volume between 1999 and 2004 (World Bank, 2008). In 2004, an Interest Drawback Programme (IDP) was implemented. Farmers borrow at the market discount rate and a rebate is provided through the IDP when loans are repaid on time. According to the CBN, ra trend analysis of the loan repayment performance of the ACGSF over the years shows that the IDP has impacted positively as it induced clients to repay on timeò Also, despite the limitations of the ACGSF, it has undoubtedly induced provision of agricultural credit, and existing monitoring and evaluation data indicate a high level of smallholder participation. Certainly, without it, most banks would not engage in lending to smallholders (World Bank, 2008). Insurance, on the other hand, is the pooling of enough small unpredictable risks so that the annual losses for the combined group are at a predictable percentage of the total. What is a burdensome risk for the individual farmer becomes in the pool an easily carried, relatively constant, annual loss expense for the insurance agency (Nelson and Murray, 1971). By paying his proportionate share or expense of the losses for the group as a whole, plus his share of the expenses of running the company, the individual is able to avoid the burden of a loss which, if it struck him alone, might put him out of business or set him back for years. The premium paid by the individual can be charged as an expense to take care of the particular risk involved. The Nigerian Agricultural Insurance Company (NAIC) was established by the Federal Government in 1987 with the following objectives:

(i) To promote agricultural production;

(ii) Provide financial support to farmers in the event of losses arising from natural disasters;

(iii) Increase the flow of agricultural credit from lending institutions to farmers, and

(iv) Minimize or eliminate the need for emergency assistance, provided by Government during periods of agricultural disasters. The minimum cultivated area to qualify for insurance is 1 hectare. Cover is available for a wide range of arable crops, either sole or in mixtures; tree crops and livestock. Larger farmers can also insure plant, equipment and buildings. Cover on insurance of arable and tree crops is limited to production costs, fixed by NAIC, with premia ranging typically from $5 \%$ to $7 \%$ of such costs. The insured pays $50 \%$ of the premium and the FGN pays the balance. Perils which are insurable relating to arable crops include diseases, pests, lightning, windstorm, flood, drought and fire. Crop and livestock insurance cover is mandatory on all loans guaranteed by the ACGSF, and those made by the NACRDB. Collection of premium is made by the lending bank which debits the borrower and pays the NAIC. The interest of the banks is stated on the insurance documents. The sole benefit of the farmer borrower is the liquidation of his debt to the bank, if he has borrowed to meet full production costs (FAO, 1991).

Linking formal and informal finance (Linkage Banking): This is an approach by which banks are linked with local financial institutions and self-help groups which serve as grassroots financial intermediaries between banks and the vast numbers of small producers and microentrepreneurs. This arrangement would require an imaginative linking of formal and informal institutions with competent NGOs, local bank branches and rotating savings and credit associations (ROSCAs), providing linking mechanisms between formal institutions and their clients. One possibility is to use the informal financial sector as f̃inancial retailersò For example, a commercial bank or 
government financial institution could lend to an affiliation of informal financial schemes which would then on-lend to their poor group members. The advantages of linkage banking include: (i) cuts down on transaction costs for both banks and customers; (ii) improves access of rural people to credit from commercial sources through local intermediaries; (iii) helps integrate local financial institutions into national financial markets; (iv) enables banks to reach out to smallholders and microentrepreneurs as a new market segment; and (v) helps preserve some of the characteristics of the informal sector which constitute its strength, namely, flexibility, rapidity, transparency of procedures and personal relationships (Saito et al., 1994). In recent years, many formal financial institutions ï mostly rural banks $i \overrightarrow{~ h a v e ~ d e v e l o p e d ~ c o l l a b o r a t i v e ~ a r r a n g e m e n t s ~}$ with susu collectors. According to Markowski (2001), collaboration has allowed for more transparency and security with clientsôdeposits and dramatically improved the liquidity position of the rural banks. At the same time, susu clients have been able to access loans from the banks for, typically, an amount up to three times their savings. Linkage banking is most developed in India, Indonesia, and The Philippines, but it is also found in other Asian and in various African countries (IFAD, 2000). It requires banks with an effective rural delivery network and local microfinancial institutions or self-help groups with sustainable operations. For example, in areas where formal financial systems are highly centralized and corrupt, it may be unwise to link them to indigenous schemes. Thus, the strengths of both informal and formal systems should be thoroughly analyzed before any links are forged between them and, whatever links are forged, local control and equity interests should be retained (Holt and Ribe, 1991).

Institutional adaptation (or downscaling or downgrading) of banks to the local environment: In virtually every developing country, there are commercial and development banks with a potential for adjustment to the banking requirements of microentrepreneurs and the poor (Seibel, 1996; Seibel, 1999). The prime prerequisite and at the same time crucial policy incentive for the institutional adjustment of banks is an interest rate regime which allows for market-oriented interest rates (Seibel, 1996). Banks must be permitted to offer attractive and differentiated interest rates to savers and to charge interest rates on loans which cover their fixed and variable costs, plus an adequate profit margin. If banks are to serve customers which differ widely in terms of service costs and risks, the only viable inducement for them is a differentiated margin, lest they exclude the small farmers and microentrepreneurs and people in remote areas. In the absence of this prime pre-requisite, banks may pursue one of the following courses: (i) they may require an exemption from the central bank; (ii) they may externalize part of their costs by working through intermediaries with separate funding (for example, NGOs); (iii) they may set up a non-bank organization with a separate legal personality (for example, a limited liability company) which does not fall under the interest rate regulation of the banking law.
However, these approaches should only be transitory and should be no long-term substitutes for interest rate de-regulation (Seibel, 1996). Institutional adaptation of banks to the microfinance market and the downscaling of their operations involves: (i) improving the business environment (reducing uncertainty and risk, and reducing costs of information gathering, client monitoring, and other transactions) and (ii) designing financial products that are attractive to both clients and providers. For this purpose, work on the commercial financial system would include activities such as: prudential supervision frameworks and specialized provisions for rural banks and financial institutions (with adapted supervision requirements); improved transfer payment networks; improved financial product definition and market identification; risk-reducing strategies (warehouse receipt collateral systems); credit bureaus to monitor repayments across sectors and across all institutions; and time-bound subsidies for experimental rural branch banking (World Bank, 1998). A decentralized delivery structure of financial services decreases information costs, reduces loan default risk, allows the growth and the diversification of the loan portfolio, creates client confidence, and promotes a sense of responsibility. For instance, the establishment of branch offices in markets, helps to better integrate financial institutions into their local communities, thus facilitating the provision of higher quality services and contributing to the long-term sustainability of the microfinance institution (Klein et al., 1999).

Institutional enhancement (or upscaling or upgrading) of non-formal financial institutions: Nonformal finance mostly rests on local institutions which are directly accessible to all segments of the population. There is a wide scope for bilateral and nongovernmental donors to enhance the capacity of institutions in the non-formal sector, particularly those which rest on self-help. By promoting non-formal institutions owned by the people, a potential may be tapped which may not immediately, and sometimes not in a long time, be reached by the banking industry. In fact there are a number of developing countries where the banking system is not amenable to serving the demands of the poorer sections of the population. In this case, upgrading non-formal financial institutions may be the only effective way for reaching the poor quickly and in large numbers. According to Seibel (1996; 1999), there are two principal approaches: (i) organizational development within the framework of their customary legal form; and (ii) promoting the transition of an institution to a higher-order legal form, particularly that of a bank or a savings and credit cooperative. These two approaches may either be directed at primary or secondary organizations to (i) enhance the capacity of grassroots financial institutions including self-help

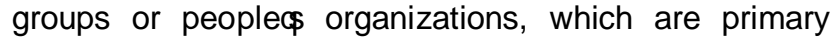
organizations, either directly or through NGOs, and (ii) enhance the capacity of NGOs as self-help promoting institutions and intermediaries. The latter are secondary organizations which in turn promote financial self-help groups including their linkages with formal finance; they 
usually have a legal status like that of a cooperative association or foundation. Successful credit programmes such as that of the Grameen Bank have infact improved on the desirable features of informal financial institutions and have integrated rather than opposed local traditional practices and institutions (downgrading of the resource institution). This process of integration and of upgrading existing informal institutions can be an important form of mobilization of indigenous resources (Chandavarkar, 1989; Levitsky and Prasad, 1990).

Institutional or infrastructural innovation: The establishment of new local financial institutions can be an appropriate approach where no suitable institutions exist or existing institutions cannot be upgraded or adjusted to local requirements. If approaches of institutional adaptation, upgrading or linkage banking are found inadequate in coping with local demands, institutional innovation can also serve as a complementary or competitive strategy and greatly contribute to institutional differentiation. Seibel (1996; 1999) lists three basic requirements for viable and sustainable institutional innovations in microfinance on a competitive market: (i) infrastructurally, they must be demand-driven, responding to felt needs and articulated demands for financial services by micro-entrepreneurs, small farmers, women and the poor in the microeconomy; (ii) institutionally, they must be savingsdriven in the interest of institutions and their customers as savers; and (iii) commercially, they must cover their costs from the margin --- the basic requirement for institutional viability. There are three types of institutions which are most likely to meet these requirements: (i) community-based financial institutions which serve a community and may be owned and controlled by a local community, (ii) member-based financial institutions which are cooperatively owned and controlled by their members; and (iii) privately-owned financial institutions, such as local shareholding banks. Mixed ownership is also possible. Depending on national and local circumstances, new institutions may be established in the formal, semi-formal or informal financial sectors. In the case of new formal financial institutions, particularly those at the grassroots level, initiatives may be taken by the central bank or major national, regional or provincial banks, including development banks and banks with a rural mandate, as facilitators or intermediaries, seconded perhaps by well-prepared NGOs in their capacity as training and consultancy agencies. In the case of new semiformal financial institutions, which usually include cooperatives and GO and NGOsupported financial programmes, appropriate partners may be cooperative or NGO networks and apex organizations which need to be adequately qualified for their task. In the case of informal financial institutions, appropriate partners may be NGOs and cooperatives, usually through their respective networks and apexes, which in turn have to provide adequate training and facilities to their member institutions. Depending on the policy framework and local conditions, infrastructural innovations may be promoted simultaneously at two or all of these levels (Seibel, 1996). In any of these cases, infrastructural innovation should be planned and implemented with a view towards the other three institutional strategies: adaptation of formal institutions, upgrading of non-formal and linkages of both formal and non-formal institutions, either as complementary or as subsequent strategies. For example, in a country deplete of any adaptable institution, intervention may start with infrastructural innovations at the informal or semiformal level; to be followed in another phase by upgrading within the nonformal framework; next by infrastructural upgrading of the most successful institutions to banks; then by linkages between nonformal and formal institutions; and eventually by a general transition to formal institutions. Before any transition to formal institutions can occur, the banking law might have to be adjusted first (Seibel, 1996).

Sound banking practices: Matching peoplêิ demand for adequate financial services with the government $\hat{\Phi}$ responsibility for macroeconomic stability and a sound financial infrastructure includes encouraging sound banking practices. Seibel (1999) has argued that the sustainability of microfinancial services hinges on two factors: (i) the soundness of financial practices, and (ii) the mobilization of internal resources. A successful institutional adaptation strategy must, therefore, encompass a sound practices strategy. This comprises improved or new financial products, good procedures and effective contractual terms and conditions. To some extent, sound practices can be applied in any policy environment and by any type of financial institution, be it formal or non-formal (Seibel, 1999). Own internal resource mobilization, on the other hand, makes microfinance institutions independent of government and donor funding. It also provides a solid basis for the sustainability of microfinancial services. Major resources include share capital, savings deposits and retained profits. For MFls operating in the microeconomy, high interest or profit-sharing rates on loans are sometimes more effective an instrument of internal resource mobilization than saving deposits (Seibel, 1999).

Promoting a conducive policy and regulatory environment: A conducive policy environment is a prerequisite for an efficient financial system, rural development and effective poverty alleviation. Of particular importance are macroeconomic stability; deregulated interest rates, exchange rates and agricultural prices; and a legal system that protects property and land-use rights, the autonomy of financial institutions and regulatory authorities, and due legal process. Stable economies contribute to reduced uncertainty, higher returns on investment and impressive lean repayment rates. Conversely, an unstable economy is likely to have erratic changes in relative prices and suddenly imposed austerity programmes which could abruptly curtail disposable income and adversely affect return on investments (Yaron, 1995). The volatile rate of inflation associated with an unstable economy would make small-scale lending and saving impractical, given the costs required to adjust repayments and the value of savings. The 
abolishment of interest rate ceilings also allows adequately priced small-scale and risky loans. When subject to interest rate ceilings, this cannot be done since the lending institution prefers to minimize its risks and administrative cost per dollar lent by lending to large less risky clients. According to Yaron (1995), the liberalization of the financial market has allowed adequate pricing of rural financial institutionsôoperations in Indonesia and has encouraged BAAC in Thailand to decrease its subsidy dependence gradually and to pursue savings mobilization as its prime growth resource to substitute for the dwindling share of Central Bank rediscounting facilities used in financing its lending activities. Also, prudential regulation and supervision of financial institutions is crucial for the evolution and stability of financial systems. Prudential regulation stipulates minimum capital adequacy ratios, limits on portfolio concentration, and guidelines for classification of assets by potential risks associated with them (Hettige, 1992). Supervision is also needed to ensure that weak financial institutions are detected early and liquidated or merged in orderly fashion. According to IFAD (2000), without properly regulated local financial institutions which mobilize savings and attract private capital, there can be no sustainable rural development. Also, while external funds may be necessary to help restructure institutions and help them get off the ground, donor and government funds should primarily be used for institution-building purposes. This includes proper training of managers, supervisors, and loan officers, and the introduction of adequate accounting, auditing, and management information systems (Braverman and Huppi, 1991). Yaron (1994) has argued that careful institution-building often constitutes the difference between a rural financial institution that could eventually become self-sustaining after a few years of support during its start-up period and another one that would need permanent subsidies and bail-outs.

\section{CONCLUSION AND RECOMMENDATIONS}

Cost-effective and sustainable financial services are important instruments for improving productivity. However, under the previous policy environment of financial repression and easy money, many programmes failed to cover their costs and recover their loans, which made them unsustainable; rural financial markets were grossly distorted and outreached stagnated. Support in recent times has shifted to rural finance systems development, institutional diversity and sustainable access of the rural poor to financial services. A critical element is a policy and regulatory framework that is conducive to the evolution of new ways of doing business, including interest rates sufficient to cover costs and innovations in risk management. The recommendations for this paper are:

(i) Many specialized agricultural credit institutions have failed because of general deficiencies in governance and public sector accountability. This has not happened to all of them, however. Thus, where formal credit institutions show real potential for catering to poor smallholders, they ought not to be discarded. Some of these institutions may be useful for providing shortterm lines of credit at unsubsidized rates. (ii) Innovative efforts should be made to explore, identify and introduce mutually- beneficial links between informal savings and credit systems and the formal sector. These links would help expand the supply of credit in rural areas, while preserving the flexibility and information advantages of informal credit arrangements. For example, NGOs could act as brokers between banks and small clientele, preparing group loans or selecting borrowers in the communities where they operate. The bank would thus be spared the costs incurred by the NGO to sort and process these borrowers and would act primarily as a wholesaler of funding and a clearing house for accounts.

(iii) Giving smallholders and other rural producers wider access to savings and credit services requires institutional growth. Group formation appears to be the best and most sustainable way of achieving low transaction costs, accountability, and efficiency. According to Braun (1992), support of group formation and training (in savings mobilization and loan management) during the early stages should be viewed, not as a subsidy, but as an investment that creates institutional capital.

(iv) Credit guarantee schemes will help credit institutions manage the risk of defaults caused by climatic and commercial crisis. According to Cleaver (1993), donor financing of seed capital for loan guarantee funds may be appropriate initially, to cushion the risk of lending by private banks entering into the agricultural sector.

(v) A sustained process of income generation requires improved access to rural financial services. Since some low-income producers who lack access to formal or officially-provided credit may have assets they can use as collateral, attention to the legal framework for collateralization of moveable property, improved registry of liens, and improved contract enforcement could provide these producers with better access to credit, either individually or as part of voluntary groups.

(vi) Since recent experience shows low-income groups to have substantial savings potential and that it is quite possible to build rural financial institutions based on the savings potential of the poor, the substitution of domestic deposits for external donor funding is crucial to curb the rentseeking and political intrusions associated with external lending schemes, improve deposit services, and increase the number of loan beneficiaries who receive and repay loans in both public and private banks. Two key advantages that will follow from this action are that: (i) the local populace will begin to identify with the banks, considering it theirs, rather than the government $\hat{\mathbf{S}}$, thus creating a depositorsavers constituency to balance the borrower domination that gives rise to the entitlement syndrome where a donor is the source of funds; and (ii) with proper decentralization or 
delegation of responsibility, the branch manager $\hat{\mathbf{s}}$ psychology will begin to change, once local deposits begin to predominate as a source of funds for new loans, hence it will no longer be acceptable to issue loans with lax evaluation and perfunctory recovery (Graham, 1992).

(vii) The delegation of loan authority and the decentralization of staff responsibilities will help bring the financial system closer to the rural clientele. It is, however, important that adequate checks and balances be established to monitor decentralized decision-making.

(viii) Financial incentives such as interest rate rebates for timely loan repayment, obligatory savings, and a gradual increase in borrowing eligibility upon timely loan repayment will help introduce financial discipline among inexperienced first-time small-scale borrowers and reduce the financial risk to credit institutions. It is also important that loan repayment patterns are flexible and adjustable to the wide variety of activities financed and their typical cash flow patterns.

(ix) The use of strict collateral requirements is frequently not compatible with the goal of extending small-scale loans to the poor or to low-to-middle-income clients. As a result, the use of alternative methods such as character references and joint liability mechanisms are very necessary.

(x) Since distortionary macroeconomic and regulatory environments hinder development of the financial sector and do not improve the poor $\hat{\Phi}$ access to credit, the removal of such distortions becomes imperative. This will involve liberalizing interest rates and lifting regulations that make it illegal for institutions to charge different interest rates to different customers.

\section{REFERENCES}

Berger, M., 1989. ñGiving women credit: The strengths and limitations of credit as a tool for alleviating povertyò World Development, 17(7): 1017-1032.

Binswanger, H., V. Balaramania, B. Rao, M.J. Bhende and K.V. Kashirsagar., 1985. Credit Markets in Rural India: Theoretical Issues and Empirical Analysis, Agricultural Research Unit Discussion Paper No. 45, The World Bank, Washington,, D.C.

Braun, J. V., 1992. ñThe development of rural financial markets in sub-Saharan Africaò In Policy Options for Agricultural Development in SubSaharan Africa, N.C. Russell and C.R. Dowswell (eds.), Proceedings of a Workshop, Airlie House, Virginia, August 22 ï 25.

Braverman, A. and M. Huppi., 1991. Împroving rural finance in developing countriesò Finance and Development, 28(1): 42 ï 44.
Chandavarkar, A. G., 1989. IInformal credit markets in support of microbusinessò In Microenterprises in Developing Countries, J. Levitsky (ed.) Intermediate Technology Publications, London.

Cleaver, K. M., 1993. A Strategy to Develop Agriculture in Sub-Saharan Africa and a Focus for the World Bank, OTechnical Paper No. 203, The World Bank, Washington, D.C.

Dessing, M., 1990. Support for Microenterprises: Lessons for Sub-Saharan Africa, Technical Paper No. 122, The World Bank, Washington, D.C.

Feder, G., T. Ouchan and T. Raparla., 1986. Land Ownership Security and Access to Credit in Rural Thailand, Agricultural Research Unit Discussion Paper No. 153, The World Bank, Washington, D.C.

Fiebig, M. 1999., ñFormal and informal financial services providers in rural financial marketsò Agriculture and Rural Development, 6(2): 33-36.

Food and Agriculture Organization (FAO). 1991., Nigeria: Rural Finance Sub-Sector Overview, Rome, Italy.

Gonzalez-Vega, C. and D.H. Graham., 1995. StateOwned Agricultural Development Banks: Lessons and Opportunitioes for Microfinance, GEMINI Technical Report No. 89, Development Alternatives Inc., Bethesda, Maryland.

Graham, D.H., 1992. r̃Designing financial intermediaries to mobilize savings and allocate investment moneyò In Policy Options for Agricultural Development in Sub-Saharan Africa, N.C. Russel and C.R. Dowswell (eds.), Proceedings of a Workshop, Airlie House, Virginia, August 23 ï 25.

Grindle, M. S., C. S. Mann and P. M. Shipton., 1987. Capacity Building for Resource Institutions for Small and Micro-enterprises: A Strategy Overview Paper, HIID.

Hettige, H., 1992. ñToward financial deepening in subSaharan Africa: An analytical frameworkò In Financial Deepening in Sub-Saharan Africa: Theory and Innovations, W.F. Steel (ed.), The World Bank, Washington, D.C.

Holt, S.L. and H. Ribe., 1991. Developing Financial Institutions for the Poor and Reducing Barriers to Access for Women, Discussion Paper No. 117, The World Bank, Washington, D.C.

Howse, C. J., 1983. r̃agricultural development without creditò In Rural Financial Markets in Developing Countries, J. D. Von Pischke, D. Adams and G. 
Donald (eds.), Johns Hopkins University Press, Baltimore.

International Fund for Agricultural Development (IFAD). 2000. IFAD Policy on Rural Finance, Rome Italy.

Klein, B., R. Meyer, A. Hannig, J. Burnett and M. Fiebig., 1999. Better Practices in Agricultural Lending, FAO/GTZ.

Leite, S.P. and V. Sundararajan., 1990. Issues in Interest Rate Management and Liberalization. IMF Working Paper (WP/90/12), International Monetary Fund, Washington, D.C.

Levitsky, J. and R. N. Prasad., 1990. Credit Guarantee Schemes for Small and Medium Enterprises, Technical Paper No. 58, The World Bank, Washington, D.C.

Lipton, M. 1989. The Poor and the Poorest: Some Interim Findings, World Bank Discussion Paper No. 25, Washington, D.C.

Lycette, M. and K. White., 1989. IImproving women⿳⺈ access to credit in Latin America and the Caribbean: Policy and project recommendationsò In Women⿳亠丷 Ventures: Assistance to the Informal Sector in Latin America, M. Berger and M. Buviric (eds.), West Hartford, Conn.: Kumarian Press, Inc.

Markowski, P., 2001. ñMicrofinance innovations in the Gulf of Guinea regionò In Food Security in a Changing Africa, S.A. Breth (ed.), Proceedings of the Workshop on Africa Food Security in a Changing Environment: Sharing Good Practices and Experiences, held in Kampala, Uganda, June 6-9.

Nelson, A.G. and W.G. Murray., 1971. Agricultural Finance, lowa State University Press.

Otero, M. 1989. A Handful of Rice: Savings Mobilization by Microenterprise Programmes and Perspectives for the Future, Monograph Series No. 3, ACCION International, Washington, D.C.
Saito, K., H. Mekonnen and D. Spurling., 1994. Raising the Productivity of Women Farmers in SubSaharan Africa, Discussion Paper No. 230, The World Bank, Washington, D.C.

Schmidt, R.H. and E. Kropp., 1987. Rural Finance, Guiding Principles, BMZ/GTZ/DSE, Bonn, Eschborn, Berlin.

Sebstad, J. 1982., Struggle and Development Among Self-Employed Women. A Report on the SelfEmployed Women⿳⺈ Association, Ahmedabad, India, Prepared for the United States Agency for International Development, Washington, D.C.

Seibel, H. D., 1989 . r̃inking informal and formal financial institutions in Africa and Asiaò In Microenterprises in Developing Countries, J. Levitsky (ed.) Intermediate Technology Publications, London.

Seibel, H. D., 1996. Financial Systems Development and Microfinance, GTZ, Eschborn.

Seibel, H. D., 1999. Strategies for Developing Viable Microfinance Institutions with Sustainable Services: The Asian Experience, Working Paper No. A3, International Fund for Agricultural Development (IFAD), Rome, Italy.

Seibel, H. D., 2001. Agricultural Development Bank Reform, Working Paper No. A7a, IFAD, Rome, Italy.

United States Agency for International Development (USAID)., 1994. Microenterprise Development Policy Paper, Washington, D.C.

World Bank., 1998. A Framework for World Bank Group Support for Development of Micro, Small Enterprise and Rural Finance in Sub-Saharan Africa, Washington, D.C.

Yaron, J., 1994. What makes rural finance institutions successful?ò The World Bank Research Observer, 9(1): 49-70.

Yaron, J. 1995. Successful Rural Finance Institutions, Discussion Paper No. 150, The World Bank, Washington, D.C. 